\title{
Progress and Prospect on Stability of Perovskite Photovoltaics
}

\author{
S. C. Ezike ${ }^{1,3 *}$, G. M. Z. Kana ${ }^{2}$, A. O. Aina ${ }^{1}$
}

${ }^{1}$ Department of Physics and Materials Science unit, Kwara State University Malete, Ilorin, Nigeria

${ }^{2}$ Department of Materials Science and Engineering, Kwara State University Malete, Ilorin, Nigeria

${ }^{3}$ Department of Physics, Modibbo Adama University of Technology, Yola, Nigeria

\footnotetext{
* Corresponding author email: chineduezike81@gmail.com
}

Received: 24 March 2017 / Revised: 27 April 2017 / Accepted: 10 May 2017 / Published: 20 May 2017

\begin{abstract}
Solar energy has the potential to solve world energy problem as it is pollution- free. It could be enhanced using perovskite material as absorber in perovskite solar cells. The history and what this material is made up of are emphasized. Different methods of fabrication, improving the power conversion efficiency (PCE) and factors influencing degradation of perovskite based solar are stated. Because of the fact that this material based solar cells are not yet developed, its stability was reviewed to bring different technology employed in tackling the stability aiming for a better understanding of the material and the devices and facilitates the commercialization of perovskite solar cell.
\end{abstract}

Keywords: Solar cell, Perovskite, Degradation, Stability, renewable energy commercialization

\section{Introduction}

Establishment of renewable energy sources has become one of the major problems faced as other traditional source of energy derails [1, 2] as it brings climate change and high societal energy demand [3-5]. Non-renewable energy accounts for most of the total energy consumption in the world as shown in Figure 1. Climate change caused by environmental pollution from the exploration and combustion of fossil fuels has posed threat to our environment and would exhaust in near future [6,7]. These have derived the passion to search for alternative energy source (renewable energy) to sustain future growing energy consumption and to reduce environmental pollution and climate change [8]. Among hydroelectricity, wind, solar geothermal and biomass out of these sources, solar source is least explored. Among all the renewable sources, solar energy gives an unimaginable amount of energy towards the Earth around $10^{17} \mathrm{~W}$ making photovoltaic (PV) technologies promising in current research. 


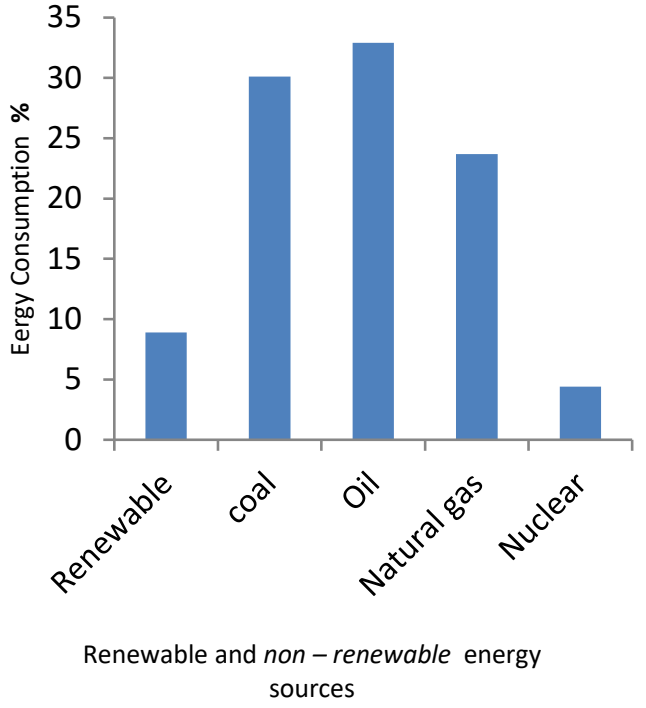

(a)

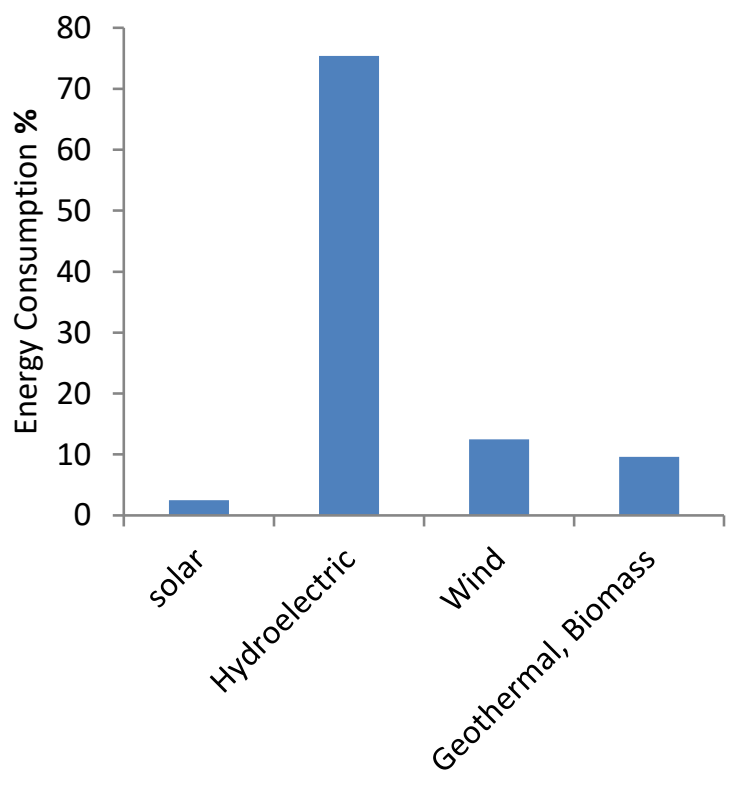

Renewable Energy Sources

(b)

Figure1: Bar chart showing percentage of -

(a) non-renewable and renewable

(b) renewable energy consumption

Energy needed by human is far less than the amount of energy from the Sun, solar energy promises a source of renewable energy $[2,9,10]$ notwithstanding that some of the radiations are lost due to scattering, absorption. Solar energy converted to heat energy in the system of concentrated solar power system can be converted to electricity or using photovoltaic (PV) to convert solar to electricity [11].

Due to the abundance of solar energy, PV technologies have numbers of advantages such as little need for maintenance, decentralization to reduce electricity transmission loss, zero noise pollution, off-grid operation to support rural areas and scalable from small mobile devices to large solar plant to suit various energy requirements [2]. A device which converts light directly from sun to electricity is solar cells. There are three generations of solar cells: first, second and third generations. The first solar cell base on crystalline silicon (c-Si) which its power conversion efficiency (PCE) has attained $25 \%$. c$\mathrm{Si}$ requires high temperature for its production, low absorption coefficient, indirect energy band gap and the installation cost is high [12]. The second generation of PV thin film (CdTe, CIGS, GaAs etc) are expensive and possess less Earth abundant elements while Dye sensitized solar cells (DSSCs), Organic solar cells, Quantum dot solar cells and Perovskite solar cells (PSCs) are the third generation PV [13]. The third generation PVs reduce the cost of the solar cells using Earth abundant elements, inexpensive fabrication (low temperature, solution processing, and roll to roll manufacturing) and easy installation (light weight and flexibility) [14 18]. Among the third generation of PVs, PSCs has achieved PCE of $3.8 \%$ in 2009 [19 - 21] and recently $22.01 \%$ in 2016 [22].

\subsection{History of Perovskite Solar Cells}

PSCs came into existence as improvement of the performance of Dye - sensitized solar cells (DSSCs). DSSC which was reported first twentysix years ago by O'Regan and Grätzel [23] opened the doors to low - cost and easy roll-to-roll fabrication solar cell technology. Photoanode $\left(\mathrm{TiO}_{2}\right)$, a dye (N719), electrolyte (iodide/triiodide redox couple) and a back electrode (platinum) are the components of DSSCs as given in Figure 2. The generated charges, electrons and holes, are taken to conduction band of photoanode and back electrode (through electrolyte) respectively [24] as shown in Figure 3. Conventional DSSCs were constructed with liquid - state electrolytes and they have reached to PCE of $13 \%$ with 
cobalt-based redox shuttle and an engineered donor- $\pi$ - acceptor dyes [25]. One of the challenges DSSCs have is improvement of their long - term stability which showed in degradation of photoanode and counter electrode, concentration drop in electrolyte redox couple, and encapsulation related issues [26].

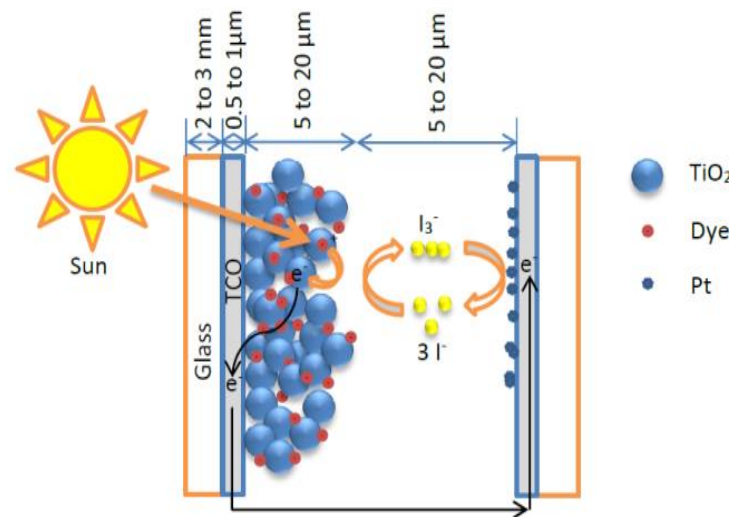

Figure 2: Structure and operation of the DSSCs reprinted from [27] with permission from $A d v$.

Mater

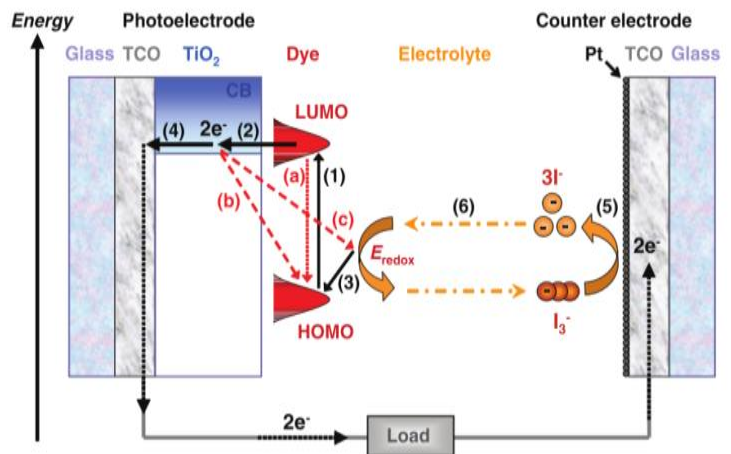

Figure 3: Electron transfer processes in the DSSCs reprinted from [27] with permission from $A d v$.

Mater

The liquid electrolyte of DSSCs could be replaced with $2,2^{\prime}, 7,7^{\prime} \quad-\quad$ tetrakis $\quad(\mathrm{N}, \mathrm{N}-$ dimethoxyphenylamine)-9,9'- spirobifluorene (spiro - OMeTAD) (solid state hole transport material (HTM)) to minimize stability issues [28]. Equally, dye was replaced by a cesium based perovskite materials which improved on the stability of the cell and this led to perovskite solar cells (PSCs). With the advent of perovskite photovoltaic as one of third generation of solar cells with PCE 22\% which has exceeded dyesensitized solar cells (DSSCs), organic solar cells (OSCs), and amorphous silicon solar cells [29], a reliable alternative energy source has emerged. Perovskite is a compound that assumes crystal structure of $\mathrm{CaTiO}_{3}$ [30,31]. The perovskite material consists of organic-metallic absorber materials, which has structure of $\mathrm{ABX}_{3}$ [32] and has a network of corner sharing BX6 octahedra [33] where

$\mathrm{A}=\mathrm{CH}_{3} \mathrm{NH}_{3}{ }^{+} / \mathrm{CH}_{3} \mathrm{CH}_{2} \mathrm{NH}_{3}{ }^{+} / \mathrm{NH}_{2} \mathrm{CH}=\mathrm{NH}_{2}{ }^{+}$, $\mathrm{B}=\mathrm{Pb}^{2+} / \mathrm{Sn}^{2+} / \mathrm{Ge}^{2+}$ and $\mathrm{X}$ halide anions $\left(\mathrm{I}^{-} / \mathrm{Cl}^{-}\right.$ $/ \mathrm{Br}^{-}$or mixtures) [34] which results in $\mathrm{CH}_{3} \mathrm{NH}_{3} \mathrm{PbI}_{3} / \mathrm{CH}_{3} \mathrm{NH}_{3} \mathrm{SnI}_{3}$.

The most frequently perovskite material use today is methylammonium lead halides $\left(\mathrm{I}^{-} / \mathrm{Cl}^{-}\right.$ $/ \mathrm{Br}^{-}$or mixtures). Since this perovskite material has shown enormous competitiveness with first and second generation solar cells, and supersedes the fellow third generation solar cells in terms of efficiency. In methylammonium lead trihalide $\left(\mathrm{CH}_{3} \mathrm{NH}_{3} \mathrm{PbX}_{3}, \mathrm{X}=\mathrm{Cl}, \mathrm{Br}\right.$ or $\left.\mathrm{I}\right)$, its degradation and toxic nature have poised setbacks towards its commercialization.

\section{The Perovskite Materials}

About one hundred and twenty thousand terawatts of solar power irradiate Earth but only fifteen terawatts are consumed by humans globally. This shows how abundant and free the solar power is, and this can be harvested with minimal effect on the environment [35]. In the quest to develop a new solar cell, organic photovoltaic (OPV) and DSSCs showed interesting with unique varying features. But PCEs of both OPV and DSSCs are far behind the commercialized silicon solar cells. This made PSCs interesting and attractive due to competitive PCE with that of silicon solar cells as a new generation PV. This material has shown high performance from 2009 to date with PCE of $3.8 \%-\sim 22 \%$ to date $[19,36,37]$. From this outstanding performance of perovskite PV, new generation of PV will emerge which is expected to relegate that of silicon based PV. Among all the organometallic halides, lead - based perovskites, exhibit highest PCE as of now over other third generation PVs. There are large possible structural variations in perovskite due to the fact that $\mathrm{A}$ and $\mathrm{B}$ can be substituted with almost all the elements in the periodic table [38]. Figure 4 below shows the structures of organic (A) and inorganic (B) materials normally used in perovskite solar cells. The tolerance factor $\tau$ is the 
determinant factor of perovskite structure as the size of $A$ and $B$ sites influence it.

$$
\tau=\frac{r_{A}+r_{X}}{\sqrt{2}\left(r_{B}+r_{X}\right)}
$$

Where $\tau$, and $r_{A, B, X}$ are tolerance factor and radius of $\mathrm{A}, \mathrm{B}$ and $\mathrm{X}$ ions respectively. When $\tau=1$ perovskite PV exhibits an ideal cubic structure, while $\tau<1$, A is too small and $\tau>1$ indicates that $\mathrm{A}$ is too large to be accommodated in the cavity between $\mathrm{BX}_{6}$ octahedrons [30]. The narrower range of $\tau$ values from $0.89-1.0$ indicates cubic structure, while lower values of $\tau$ stabilize less symmetric tetragonal and orthorhombic structures. Where $0.81<\tau<1.11$ is the values for halide perovskites. The octahedral factor $\mu$ determines the crystallographic stability of perovskites. It is expressed as

$$
\mu=\frac{r_{B}}{r_{X}}
$$

where $0.44<\mu<0.90$ is the typical values for halide perovskites [39]. The respective ionic radii are $r_{\mathrm{CH}_{3} \mathrm{NH}_{3}}{ }^{+}=0.18 \mathrm{~nm}[40], \mathrm{r}_{\mathrm{CH}_{3} \mathrm{CH}_{2} \mathrm{NH}_{3}}{ }^{+}=$ $0.23 \mathrm{~nm}$ [41] - [44], $\mathrm{C}_{\mathrm{CH}_{2} \mathrm{CH}=\mathrm{NH}_{2}}{ }^{+} \sim 0.19-$ $0.22 \mathrm{~nm}$ [45] - [47], $r_{\text {Iodine }}=0.220 \mathrm{~nm}$, $r_{\text {Bromine }}=0.196 \mathrm{~nm}, r_{\text {Chlorine }}=0.181 \mathrm{~nm}$, $r_{\text {Lead }}=0.119 \mathrm{~nm}$ and $r_{\text {Tin }}=0.110 \mathrm{~nm} \mathrm{[47].}$ One of the problems in lead - based perovskite $\mathrm{PV}$ is the toxic nature of lead in these cells, which imposes threat in commercialization. Elements from group four and other divalent elements can replace lead [11, 29, 32].

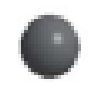

Cesium

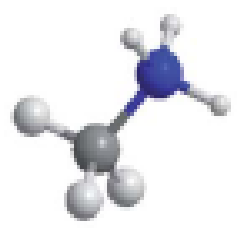

Methyammonium

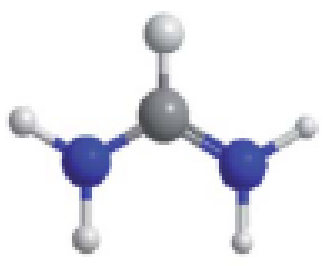

Formamidinium
Figure 4: The atomic structure of three Organic site cations excerpted from [45]

Combining N719 with tin based - inorganic halide $\left(\mathrm{CsSn}_{3}\right)$ enhanced PCE to $8.5 \%$ [48]. It was recorded that mixed-halide organicinorganic hybrid perovskites has diffusion length of more than $1 \mathrm{~mm}$ [49]. Because of the toxicity of lead in Lead - based perovskite PV which may impede its commercialization, lead - free perovskite PVs have to be optimized.
Methylammonium tin iodide $\left(\mathrm{CH}_{3} \mathrm{NH}_{3} \mathrm{SnI}_{3}\right)$ as the light-absorbing material has $1.3 \mathrm{eV}$ energy band gap which can absorb all solar spectrum [50]. Tin based perovskite PV contains Sn which oxidizes from $\mathrm{Sn}^{2+}$ to $\mathrm{Sn}^{4+}$ which is metal like because of the band gap [42,49,51]. Despite this problem in Sn based perovskite PV, [50] and reported a working Sn-based PV.

\subsection{Methods of Fabrications}

The major methods of fabricating perovskite solar cells which are Spin - coating, Vapour deposition and thermal evaporation methods. Spin -coating methods include one - step, two step/ sequential deposition [40,52, 53], and vapour deposition method which include vapour - assisted deposition , and dual - source vapour deposition[54], and thermal evaporation technique (dual source approach)have been used to prepare $\mathrm{CH}_{3} \mathrm{NH}_{3} \mathrm{PbX}_{3}$ materials. Different device architectures such as planar [55] and mesostructured cell $[40,56]$ have been proposed.

\subsubsection{Spin - Coating Deposition Processes}

The metal halide and organic halide are dissolved in organic solvents which follow by deposition on a substrate and formation of the perovskite is achieved through annealing around $100^{\circ} \mathrm{C}$. This method is a low-cost approach but it wastes a lot of precursors.

\subsubsection{One-Step Method}

In one - step method as shown in Figure 5, both the organic and inorganic halides are stoichiometrically prepared in a common solution and are then spin coated into a thin film.

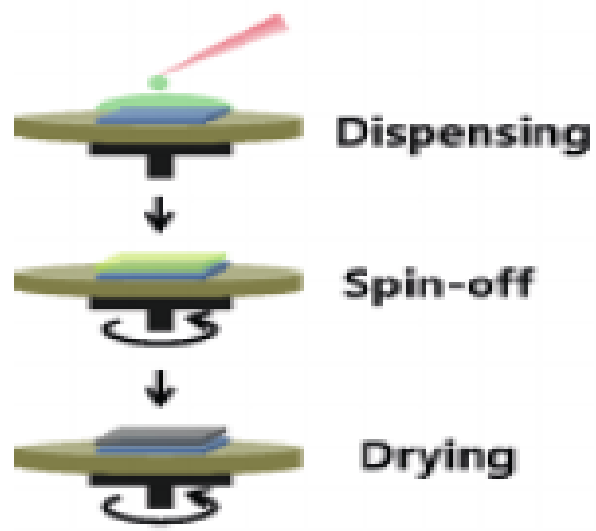

Figure 5: One - step spin-coating method of fabricating perovskite solar cells [57] 
Ezike et al., J. Mod. Mater.; Vol. 4, Issue 1, pp: 16-30, 2017

Mesostructural architecture was used to obtain first high-performance devices by depositing the mixture on mesoporous n-type $\mathrm{TiO}_{2}$ or insulating $\mathrm{Al}_{2} \mathrm{O}_{3}$ scaffold substrates and the scaffolds were on top of a thin n-type compact $\mathrm{TiO}_{2}$ layer [37]. However, spin-coating the mixture directly onto the compact n-type contact, as in planar hetero-junction architectures, initially resulted in a dewetting effect, [53] leading to poor surface coverage [52]. This in turn resulted in poor device performance as a result of high series resistance paths and low light absorption in the solar cell. The surface coverage and device performance are both highly dependent on the processing conditions.

It was found that treatment in a nitrogen atmosphere, optimizing the spin-coating protocol, and lowering the annealing temperature to $90{ }^{\circ} \mathrm{C}$ improves coverage (>90\%) and film morphology, with devices reaching a PCE of more than $12 \%[45,54]$. Also, PCE of $\sim 20$ has been achieved by [55] using single step solution method to fabricate perovskite solar cell based on composite of methylammonium lead iodide with formamidinium lead bromide. With respect to improved coverage, there is non- uniformity of films thickness in spin-coated films across the substrates and this reduces the chances of solution processed films to be reproducible and their optimization is not assured.

\subsubsection{Two - Steps Method}

In two-step deposition method as shown in figure 6 , two precursor solutions are prepared.

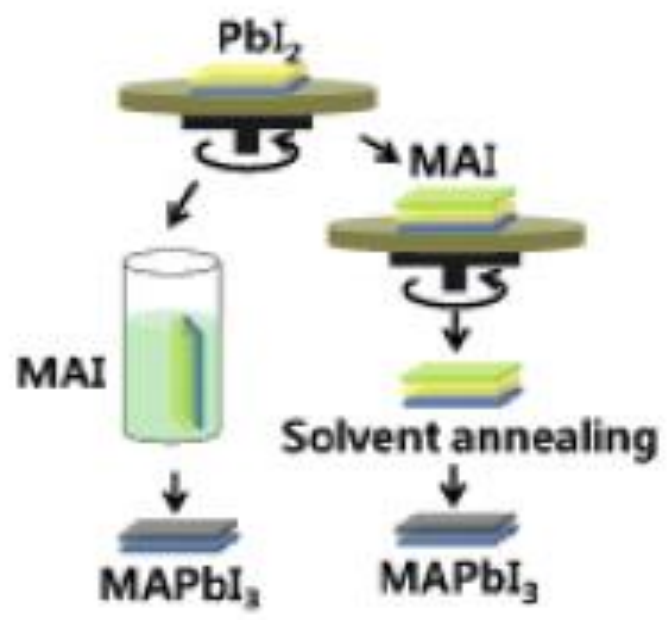

Figure 6: Two - steps spin-coating method of fabricating perovskite solar cells [57]
A thin film of metal halide precursor (e.g., $\mathrm{PbI}_{2}$ ) is first deposited and then the film coated substrate is dipped into the second precursor solution. Using two - step sequential method controls the morphology of the two precursors [56]. In the sequential-deposition method, Burschka et al. [58] exposed film with a solution of $\mathrm{PbI}_{2}$ infiltrated in a mesoporous $\mathrm{TiO}_{2}$ to a solution of MAI which latter formed $\mathrm{MAPbI}_{3}$ with the existence of capping layer. This achieved PCE of $15.3 \%$. Where the perovskite materials were infiltrated without forming capping layer PCE of $13 \%$ was achieved. In the work of Huang et al. [59] showed that planar perovskite films prepared by usual spin - coating always exhibit a dendritic grain morphology resulting too many gaps, poor coverage of the substrate and low PCE. PCE of $\sim 17$ [60] using architecture of FTO/bl- $\mathrm{TiO}_{2} / \mathrm{mp}-\mathrm{TiO}_{2} /$ cuboid-

$\mathrm{CH}_{3} \mathrm{NH}_{3} \mathrm{PbI}_{3} /$ Spiro-OMeTAD/Au was using two - step method of fabrication. $\mathrm{CH}_{3} \mathrm{NH}_{3} \mathrm{SnI}_{3}$ was deposited using solution method in mesoporous $\mathrm{TiO}_{2}$ scaffold but showed poor surface coverage and homogeneities $[11,33]$. The poor film quality and low surface coverage which caused interfacial recombination attributed for weak performance of tin perovskites compare to $\mathrm{Pb}-$ based materials $[50,58]$. In a different work, with a similar $\mathrm{CH}_{3} \mathrm{NH}_{3} \mathrm{SnI}_{3}$ perovskite materials having slightly lower bandgap energy of $1.23 \mathrm{eV}$, Snaith et al. [32] reported a solar cell with efficiency of $6.4 \%$. In addition, the chargediffusion length in such solution-processed $\mathrm{CH}_{3} \mathrm{NH}_{3} \mathrm{SnI}_{3}$ films was determined to be $30 \mathrm{~nm}$ [11], whereas $\mathrm{CH}_{3} \mathrm{NH}_{3} \mathrm{PbI}_{3}$ exhibits diffusion lengths of around $100 \mathrm{~nm}$ and $\mathrm{CH}_{3} \mathrm{NH}_{3} \mathrm{PbI}_{3-\mathrm{x}} \mathrm{Cl}_{\mathrm{x}}$ of more than $1 \mu \mathrm{m}$ [54].

\subsubsection{Vapour Deposition}

In this method of deposition, the substrate is exposed to one or more volatile precursors, which react with the substrate and / or decompose to produce the wanted deposit. It can be when the metal halide is deposited by spin coating or other methods and volatile organic halide is deposited by ejecting it to give out vapour in the reaction chamber. 


\subsubsection{Vapour Assisted Deposition Method}

The volatile produced by-products are ejected by passing gas through the reaction chamber

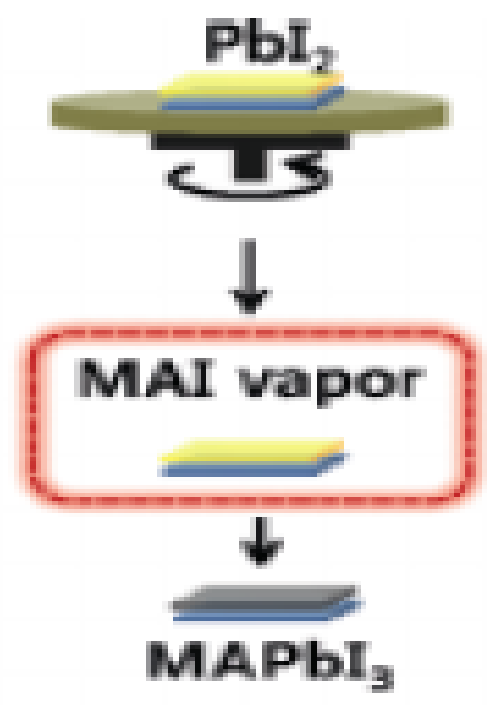

Figure 7: Vapor assisted method of fabricating perovskite solar cells [57]

In Figure 7, spin-coated deposition of $\mathrm{PbI}_{2}$ precursor was done followed by evaporation of methyl ammonium iodide (MAI) onto the asdeposited $\mathrm{PbI}_{2}$ film which yielded PCE of $\sim 12 \%$ [61]. Generally, vapor-deposited hybrid perovskite films are known to be more homogeneous and provide a higher surface coverage than solution-processed films [51]. In the work of Huang et al. [59] the films prepared by conventional spin - coating method was compared with the films prepared by argon gas assisted method and it was found that the latter had a full coverage on the $\mathrm{TiO}_{2}$ dense blocking layer while former resulted in poor coverage of the surface. In the case of gas - assisted spin coating, high supersaturation was created and it led to production of large number of uniformly distributed nuclei before occurrence of rapid growth. Comparing their photovoltaic performances, the devices produced by gas assisted method showed significant improvement with PCE of $14.1 \pm 0.4 \%\left(100^{\circ} \mathrm{C}\right)$ while that of conventional spin- coated devices gave PCE of $4.6 \pm 1.1 \%\left(100^{\circ} \mathrm{C}\right)$. The low PCE in conventional spin - coated distribution of the films led to variation in film thickness. The investigation temperature effect on thermally annealed gas - assisted perovskite film showed increase in grain size due to Ostwald ripening. There was better visible absorption due to full crystallization of the perovskite. Annealing above the phase transformation temperature produced devices with much better photocurrents and fill factors, and higher PCE.

\subsubsection{Dual Source Vapour Deposition Method}

This involves simultaneous evaporation of organic and inorganic salts from respective sources at high vacuum. PCE of $\sim 12 \%$ was achieved using this method [51]. This fabrication technique is shown in Figure 8.

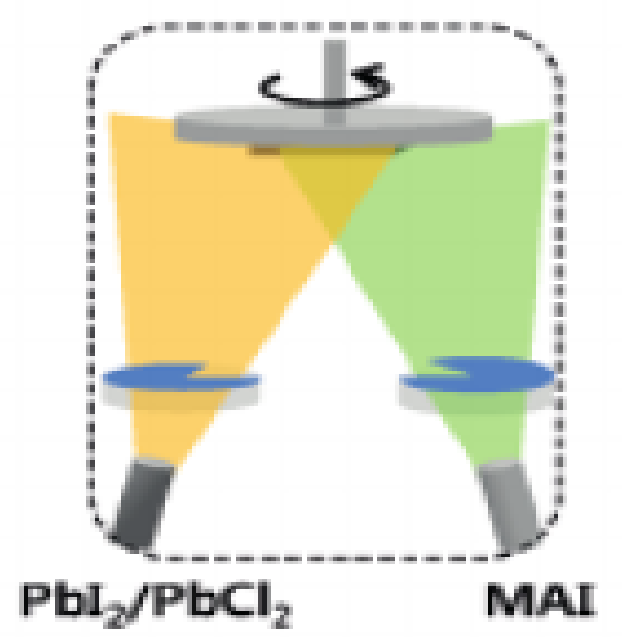

Figure 8: Dual - source vapour deposition method of fabricating perovskite solar cells [57]

Dual source of organic and inorganic halide ejects the vapours to the substrate exposed in the chamber. It is a low-cost method, uniform step coverage, fast deposition, low processing temperature and high throughput. Also, Weiss et al. [2] in their research discovered that two - step process using vapor deposition and spin coating to deposit $\mathrm{SnI}_{2}$ and methylammonium iodide (MAI), respectively. They achieved complete surface coverage and good film quality. They equally found that increase of MAI concentration $(10-20 \mathrm{mg} / \mathrm{mL}$ at $6000 \mathrm{rev} / \mathrm{mins})$ led to smaller particle size and homogeneity of films. The films were of improved stability against decomposition at air and even under illumination compared to $\mathrm{CH}_{3} \mathrm{NH}_{3} \mathrm{SnI}_{3}$ materials studied earlier $[11,33]$. Thus, $\mathrm{CH}_{3} \mathrm{NH}_{3} \mathrm{SnI}_{3}$ consists of a material that has good prospects to be successfully used as absorber layers in leadfree perovskite solar cells. 


\subsubsection{Thermal Evaporation}

This is the widely used technique for preparation of thin films for deposition of metals, alloys and many compounds. The requirement is to create vacuum environment where enough heat is given to the evaporants to attain vapour pressure required for evaporation [62]. The evaporated materials are allowed to condense on the substrate kept at a suitable temperature [30]. The level of vacuum is factor that determines both the contamination rate in the depositing films and possibilities of scattering of the beam of atoms going out of evaporation sources. High vacuum creation in evaporator would lie within the conventional ultimate pressure of $10^{-3}\left(10^{-8} \mathrm{~atm}\right)$ to $10^{-6} \mathrm{~Pa}$. [63] the pressure range is enough to prevent gas scattering between the source and the substrate [30]. The films are deposited via condensation of the vapour onto a colder substrate. At this pressure, a straight-line path for the vaporized atoms is ensured for a substrate to source distance of nearly 10 to $50 \mathrm{~cm}$. While thermal evaporation technique is applied to deposited films of inorganic materials, it is being used for deposition of organic materials of low molecular weight by formation layers. The characteristics and quality of the deposited film will depend on the substrate temperature; rate of deposition [64], ambient pressure etc. and the uniformity of the film depends on the geometry of the evaporation source and its distance from the source. It has been reported that using a dual - source co-evaporation of $\mathrm{MAI}$ and $\mathrm{PbCl}_{2}$, highly uniform $\mathrm{MAPbI}_{3-\mathrm{x}} \mathrm{Cl}_{\mathrm{x}}$ films with almost $100 \%$ surface coverage was obtained followed by annealing at $100{ }^{\circ} \mathrm{C}$, high PCE of $15.4 \%$ was achieved and have the advantage of producing pin - hole free layers. However, this method needs high amount of energy for film fabrication [51].

\subsection{Improvement of Power Conversion Efficiency}

The details of organometallic perovskites as regards band gap, optical absorption, carrier effective mass by Frost et al. [65] using density functional tool to understand the PV performance contribution showed that this material has spontaneous electric polarization.
This electric polarization which gives rise to ferroelectric domains leads to internal junctions that separate the electron - hole pairs. Wannier Mott exciton and ionization of donor - acceptor defects are dominant since there are existence of high dielectric constant and low effective mass. They suggested that the nano-structured films use the principles of photoelectric effect to get higher open voltage which led to the hysteresis observation PSCs. Kim et al. [66] reported on how photovoltaic performance perovskite material $\left(\mathrm{CH}_{3} \mathrm{NH}_{3} \mathrm{PbI}_{3}\right)$ depends on the variations of length through control of reaction time of rutile $\mathrm{TiO}_{2}$. Increase in the length of $\mathrm{TiO}_{2}$ nanorod give rise to decrease in the cells PCE. Ko et al. [67] fabricated perovskite solar cell using two - steps spin - coating method under high relative humidity condition which achieved high PCE of $15.76 \%$ with the consideration of substrate pre-heating temperature being paramount. It was discovered that pre - heating of the substrate led to infiltration of $\mathrm{PbI}_{2}$ in the mesopores of $\mathrm{TiO}_{2}$ films with full coverage. The optimum pre - heating temperature was $50^{\circ} \mathrm{C}$. The authors equally investigated the effect of heating the substrates before fabrication of cells which gave a lower PCE of $10-11 \%$. According to Stranks et al. [35]; the origin of traps, which has been unclear, could arise from vacancies in the materials reduces the performance of the cells and can be minimized by increasing the crystal's domain size and thin film's uniformity. Kim et al. [66] used impedance spectroscopy to determine how and where charge accumulation is located in $\mathrm{CH}_{3} \mathrm{NH}_{3} \mathrm{PbI}_{3}$ nanostructure solar cell for PV devices performance. Accumulation of charge was observed in $\mathrm{CH}_{3} \mathrm{NH}_{3} \mathrm{PbI}_{3}$ material and the characterized cell made up of new PV device in between sensitized and thin film PV with $\mathrm{ZrO}_{2}$ scaffold.

\subsection{Factors Influencing Degradation in PSCs}

According to Li et al. [68], four major external factors were pointed out being responsible for degradation mechanisms in perovskite solar cells. They are moisture, UV - light irradiation, temperature and oxygen [69]. 


\subsubsection{Moisture}

In the case of moisture, it was discovered that it has a positive and equally negative effects on perovskite solar cells. Building up process in film formation and grain boundary movement by controlled humidity condition leads to large crystal formation and reduction in film pinholes [70]. This film reconstruction hastens nucleation and crystallization of perovskite phase [71]. Little quantity of water helps in making the perovskite films smooth and dense [72].

UV- Vis absorption and XRD measurements on the $\mathrm{CH}_{3} \mathrm{NH}_{3} \mathrm{PbI}_{3}$ films were conducted by Niu et al. $[73,74]$ before and after exposing the films for 18 hours in $60 \%$ relative humidity under sunlight at temperature of $35^{\circ} \mathrm{C}$. The absorption peaks of the perovskite ranges from $530-800 \mathrm{~nm}$ was decreased instantly and $\mathrm{PbI}_{2}$ absorption peaks $<$ $520 \mathrm{~nm}$ was remained. The diffraction peaks of $\mathrm{CH}_{3} \mathrm{NH}_{3} \mathrm{PbI}_{3}$ in XRD were absent thereby given rise to new peaks of $\mathrm{PbI}_{2}$ after aging. Degradation reaction of the perovskite film exposed to moisture was suggested.

$$
\begin{aligned}
& \mathrm{CH}_{3} \mathrm{NH}_{3} \mathrm{PbI}_{3}(s) \stackrel{\mathrm{H}_{2} \mathrm{O}}{\rightarrow} \mathrm{CH}_{3} \mathrm{NH}_{3} \mathrm{I}(a q)+\mathrm{PbI}_{2}(s) \\
& \mathrm{CH}_{3} \mathrm{NH}_{3} \mathrm{I}(a q) \leftrightarrow \mathrm{CH}_{3} \mathrm{NH}_{2}(a q)+\mathrm{HI}(a q) \\
& 4 \mathrm{HI}(a q)+\mathrm{O}_{2}(g) \leftrightarrow 2 \mathrm{I}_{2}(s)+2 \mathrm{H}_{2} \mathrm{O}(l) \\
& 2 \mathrm{HI}(a q) \stackrel{\mathrm{hv}}{\leftrightarrow} \mathrm{H}_{2}(g)+\mathrm{I}_{2}(s)
\end{aligned}
$$

Degradation process examined using grazing incidence $\mathrm{X}$-ray diffraction (GIXRD) was and formation $\left(\mathrm{CH}_{3} \mathrm{NH}_{3}\right)_{4} \mathrm{PbI}_{6} \cdot 2 \mathrm{H}_{2} \mathrm{O}$ intermediate containing isolated $\mathrm{PbI}_{6}{ }^{4-}$ octahedral was attributed to beginning decomposition of perovskite under $80 \%$ humidity exposure. The appearance of new phase which was neither assigned to $\mathrm{CH}_{3} \mathrm{NH}_{3} \mathrm{PbI}_{3}$ nor $\mathrm{PbI}_{2}$ showed the formation of new intermediate crystalline phase [75]. Also, it was verified that there is existence of new intermediate crystalline phase in water induced degradation of perovskite [76]. Using abnitio molecule dynamic simulations, interface between water molecule and perovskite material was analyses and showed that $\mathrm{CH}_{3} \mathrm{NH}_{3} \mathrm{I}-$ terminated group seems soluble while $\mathrm{PbI}_{2}-$ terminated surfaces is less susceptible to water [77]. Also, Huan et al. [78] performed the stability of the $\mathrm{CH}_{3} \mathrm{NH}_{3} \mathrm{PbI}_{3}$ perovskite solar cells sealed by method A was examined under three different environmental conditions (i, ii and iii). At low temperature and low humidity conditions (condition (i)), the cells were the most stable and showed almost no photodegradation. At higher temperatures and low humidity conditions (condition (ii)), the cells were less stable and the least stable at high temperature and high humidity conditions (condition (iii)) as shown in Figure 9. It shows that environmental humidity has more effect than temperature on the device stability under test conditions (ii) and (iii).

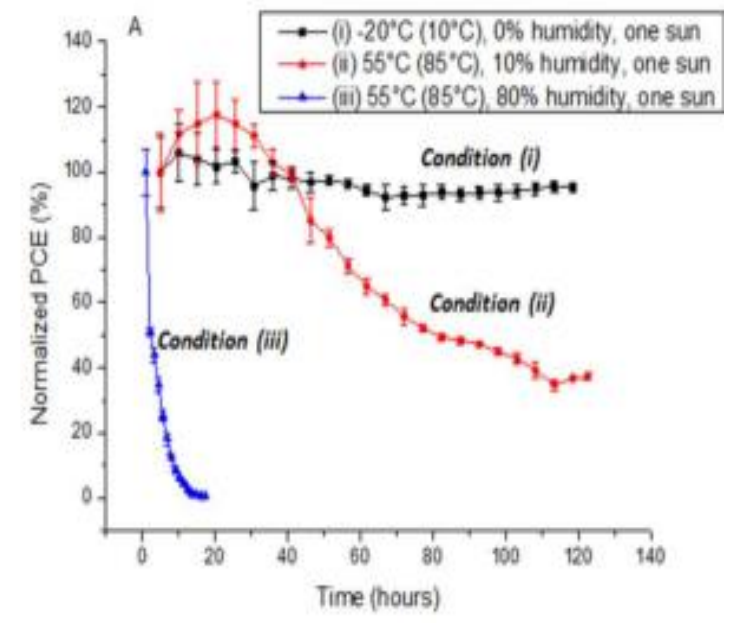

Figure 9: Perovskite solar cells sealed under different humidity for test of stability with permission from [78], J. Mater. Chem. A

\subsubsection{Oxygen}

Oxygen molecules degrade perovskite materials in the work under illumination and dry atmosphere which led to $\mathrm{CH}_{3} \mathrm{NH}_{3} \mathrm{PbI}_{3}$ photoexcitation of electrons reacting with oxygen molecule to form superoxide $\left(\mathrm{O}_{2}^{-}\right)$. Reaction between superoxide and methylammonium cation is due to decomposition of the perovskite material which led to formation of water molecule, iodine and $\mathrm{PbI}_{2}$ [79]. The water as the by- production then participate in further degradation.

$$
\begin{gathered}
\mathrm{CH}_{3} \mathrm{NH}_{3} \mathrm{PbI}_{3} \leftrightarrow \mathrm{O}_{2} \stackrel{\mathrm{CH}_{3} \mathrm{NH}_{3} \mathrm{PbI}_{3}}{=} \mathrm{O}_{2}^{-} \\
\mathrm{O}_{2}^{-}+\mathrm{CH}_{3} \mathrm{NH}_{3} \mathrm{PbI}_{3} \stackrel{\text { deprotonation }}{=} \mathrm{CH}_{3} \mathrm{NH}_{2} \\
+\mathrm{PbI}_{2}+\frac{1}{2} \mathrm{I}_{2}+\mathrm{H}_{2} \mathrm{O}
\end{gathered}
$$

\subsubsection{UV Light Irradiation}

Investigation on $\mathrm{TiO}_{2}$ - based PV subjected at $40^{\circ} \mathrm{C}$ under full sunlight showed that the 
unsealed device with UV filter was more resilience than the sealed device in an inert atmosphere. The charge collection efficiency of the encapsulated device deteriorated after exposure to laser, which was more than that of un-encapsulated ones [80]. Adsorbed oxygen in ambient atmosphere form $\mathrm{O}_{2}-\mathrm{Ti}^{4+}$ charge complex and electron - hole pair is generated on the $\mathrm{TiO}_{2}$ during exposure to UV- light. There is a release of absorbed oxygen due to recombination of hole at the valence band with the electron at oxygen adsorption site. The performance of the device reduces as the oxygen vacancy sites spreads on the surface of $\mathrm{TiO}_{2}$ which enhances recombination of electron and hole.Study of Perovskite device under light irradiation based on structural architecture of FTO/ $\mathrm{TiO}_{2} / \mathrm{CH}_{3} \mathrm{NH}_{3} \mathrm{PbI}_{3} / \mathrm{CuSCN} / \mathrm{Au}$ [81], showed that a surface blocking layer is needed between $\mathrm{TiO}_{2}$ and perovskite to enhance efficient charge separation in the device. The possible degradation reactions as suggested by the authors are:

$2 I^{-} \leftrightarrow I_{2}+2 e^{-}$

$3 \mathrm{CH}_{3} \mathrm{NH}_{3}{ }^{+} \leftrightarrow 3 \mathrm{CH}_{3} \mathrm{NH}_{2}(\mathrm{~g})+3 \mathrm{H}^{+}$

$H^{-}+I_{2}+3 H^{+} \leftrightarrow 3 H I(g)$

\subsubsection{Temperature}

Temperature degrades the performance of perovskite solar cell. Heat treatment enhanced clear structural change at $85^{\circ} \mathrm{C}$ in $\mathrm{CH} 3 \mathrm{NH} 3 \mathrm{PbI} 3$ is paramount in the formation of perovskite films [82]. Investigation under $\mathrm{N}_{2}, \mathrm{O}_{2}$ and $50 \%$ relative humidity in dark for 24 hours of perovskite properties showed that morphology of films treated in ambient condition when compared with pristine films where hardly recognized due to degradation. The samples treated in $\mathrm{N}_{2}$ and $\mathrm{O}_{2}$ were found to have degraded due to morphological changes appearance. Phillipe and co-workers [83] demonstrated the thermal stability of perovskite material using photoelectron spectroscopy (PES) through the evolution of the $\mathrm{I} / \mathrm{Pb}$ and $\mathrm{N} / \mathrm{Pb}$ ratios at room temperature and heat treatment at $100^{\circ} \mathrm{C}$ for 20 minutes and $200^{\circ} \mathrm{C}$ for 20 minutes and noticed both ratios reduced linearly with increase in temperature. After $200^{\circ} \mathrm{C}$, the ratios of $\mathrm{I} / \mathrm{Pb}$ and
$\mathrm{N} / \mathrm{Pb}$ reduced to 2.0 and 0 , respectively, which showed $\mathrm{PbI}_{2}$ total conversion. Misra et al. [84] demonstrated that the degradation by photoinduced decomposition is thermally accelerated. Leong et al. [85] in study of device performance temperature dependent at range of $80-360 \mathrm{~K}$ where the PCE increased at $\mathrm{T}<330 \mathrm{~K}$ and decreased at temperature range of $330-360 \mathrm{~K}$. The Voc at low temperature range $(\mathrm{T}<250 \mathrm{~K})$ maintained within $1.0-1.1 \mathrm{~V}$ and declined at temperature range of $220<\mathrm{T}<360 \mathrm{~K}$ [85].

\section{Stability of Perovskite Solar Cells}

\subsection{Mixed Halides}

Studies have shown that to obtain stable perovskite material, combining two or more halides is needed. In the work that adopted $\mathrm{CH}_{3} \mathrm{NH}_{3} \mathrm{~Pb}\left(\mathrm{I}_{1-\mathrm{x}} \mathrm{Br}_{\mathrm{x}}\right)_{3}$ as the light absorbing layer in PSCs. Using different amount of Br showed several degradation behaviors exhibited by the devices. The ones with $\mathrm{x}=0.2,0.29$ were less sensitive to humidity than $\mathrm{x}=0,0.06$ under 20 days aging tests which the PCE degraded more [69]. Also, researchers [86] adopted mixed halide approach to prolong the stability of devices. In the work where $\mathrm{CH}_{3} \mathrm{NH}_{3} \mathrm{~Pb}(\mathrm{SCN})_{2} \mathrm{I}$ was compared with $\mathrm{CH}_{3} \mathrm{NH}_{3} \mathrm{PbI}_{3}$ under the influence of moisture ( $95 \%$ relative humidity), it was discovered that $\mathrm{CH}_{3} \mathrm{NH}_{3} \mathrm{~Pb}(\mathrm{SCN})_{2} \mathrm{I}$ showed enhanced moisture resistance than $\mathrm{CH}_{3} \mathrm{NH}_{3} \mathrm{PbI}_{3}$ [87].

\subsection{Replacement of Cations}

Equally, changing the organic cation with larger ones improves the stability of a device [87]. Group of researchers tested the stability of formamidinium lead iodide $\left(\mathrm{FAPbI}_{3}\right)$ and methylammonium lead iodide $\left(\mathrm{MAPbI}_{3}\right)$ and concluded that $\mathrm{FAPbI}_{3}$ was more stable than $\mathrm{MAPbI}_{3}$ at $150{ }^{\circ} \mathrm{C}$ when exposed in air for half an hour [88]. Replacement of lead with bismuth (Bi) in perovskite defect materials $\left(\mathrm{CH}_{3} \mathrm{NH}_{3}\right)_{3} \mathrm{Bi}_{2} \mathrm{I}_{9}$ (MBI) exposed for forty days in ambient air showed no clear degradation. This shows that defect perovskite material may be viable option for perovskite PV stability [89]. 


\subsection{Film Morphology}

The quality of the film also affects the photovoltaic performance as well as its stability. Poor quality Films degrade quickly in ambient condition. Burschka et al. [58] prepared perovskite film with controllable morphology using two - step sequential deposition technique and the device after exposed to light intensity of $\sim 100 \mathrm{mWcm}^{-2}$ at $45^{\circ} \mathrm{C}$ for more than 500 hours, it remained $80 \%$ of its original photovoltaic performance. In a work that prepared mixed halide perovskite of $\mathrm{CH}_{3} \mathrm{NH}_{3} \mathrm{PBI}_{3-\mathrm{x}} \mathrm{Cl}_{\mathrm{x}}$ through inter-diffusion process (two - step deposition method) and $\mathrm{CH}_{3} \mathrm{NH}_{3} \mathrm{PBI}_{3}$. It was noticed that $\mathrm{CH}_{3} \mathrm{NH}_{3} \mathrm{PBI}_{3-\mathrm{x}} \mathrm{Cl}_{\mathrm{x}}$ film improved in morphology with smooth, free pin - hole and uniform surface coverage of the film. When compared with $\mathrm{CH}_{3} \mathrm{NH}_{3} \mathrm{PBI}_{3}$, it was found that no degradation was found in $\mathrm{CH}_{3} \mathrm{NH}_{3} \mathrm{PBI}_{3-\mathrm{x}} \mathrm{Cl}_{\mathrm{x}}$ device [58]. Depositing mixture of $3 \mathrm{CH}_{3} \mathrm{NH}_{3} \mathrm{I}: \quad \mathrm{PbCl}_{2}$ precursor solutions through one - step deposition method and annealed in a glove box. The crystalline quality influenced by residue of $\mathrm{CH}_{3} \mathrm{NH}_{3} \mathrm{Cl}$ byproduct and this facilitated degradation of the films. This resulted as $\mathrm{CH}_{3} \mathrm{NH}_{3} \mathrm{Cl}$ would absorb water in air. Adopting vacuum-assisted thermal annealing method, the $\mathrm{CH}_{3} \mathrm{NH}_{3} \mathrm{Cl}$ was removed totally, which gave quality film. When tested for stability after exposure to humidity, the annealed films in the glove degraded within 2 hours while that of vacuum-assisted thermal annealed at the same aging condition remained up to one month.

Chen et al. [90] added ethyl ammonium iodide (EAI) into mixed $\mathrm{PbCl}_{2}: \mathrm{CH}_{3} \mathrm{NH}_{3} \mathrm{I}$ perovskite precursor solution and the thermal stability test of temperature $65^{\circ} \mathrm{C}$ and nitrogen treated devices were found to retain $80 \%$ and $60 \%$ of their original PCE for the periods of 360 and 580 hours, respectively. Kim et al. [91] used nonsolution technology to prepare perovskite films and they demonstrated superior stable films.

\subsection{Interfacial Modifications in PSCs}

Qian et al. [92] investigated the modification of anode and cathode interfaces using poly $(3,4-$ ethylene dioxythiophene): poly (4 styrenesufonate) (PEDOT:PSS) doped silver nanoparticle (Ag NPs) and introducing solution of bathophenanthroline (sBphen) in $\mathrm{CH}_{3} \mathrm{NH}_{3} \mathrm{PbI}_{3-\mathrm{x}} \mathrm{Cl}_{\mathrm{x}}$ based planar perovskite solar cells. The electric property of PEDOT: PSS - Ag NPs composite was enhanced as Ag NPs distributed in it and equally the s $\beta$ phen interface layer filled the pin holes as it modified the surface morphology of Perovskite/Phenyl - $\mathrm{C}_{61}$ - butyric acid methyl ester $\left(\mathrm{PC}_{61} \mathrm{BM}\right)$ films. This gave improved PCE of $15.75 \%$ [92].

According to the paper of [93], the interfacial layer in polymer PVs boosts the device performance and robust device operation stability. Incorporation of interfacial layers enhanced optical and electrical properties which improved the PCE greater than $10 \%$. Also, the presence of interfacial layer in polymer solar cells can alter the active layer film morphology.

\subsection{Other Components of PSCs}

Other components in the PSCs device structure like architectural design, hole transport layers and electron transport layers contribute to the decomposition of perovskite device [68].

\subsubsection{Hole Transport Materials (HTMs)}

The hole transport materials commonly use in conventional and inverted structures are spiroOMeTAD and PEDOT:PSS, respectively. Due to acidic and hygroscopic nature of PEDOT: PSS [68], it can damage indium doped titanium oxide (ITO) and lead to low stability of PSCs.

Poly [2,6-(4,4-bis-potassiumbutanylsulfonate 4H- cylopenta-[2,1-b;3,4-b']-dithiophene]-alt- 4, 7- (2,1,3-benzothiadiazole)] (CPE-K), a $\mathrm{pH}$ neutral organic semiconductor, can replacePEDOT: PSS as hole transport materials. This hole transport material when used in perovskite material with uniform film and complete surface coverage with high PV performance improved stability in air when compared with PEDOT: PSS under the same condition. Inorganic hole transport materials like $\mathrm{Cu}: \mathrm{NiO}_{\mathbf{x}}$ [91], $\mathrm{NiO}_{x}$, reduced graphene oxide (RGO), all showed higher stability when compared with PEDOT:PSS. Addition of $\mathrm{GeO}_{2}$ to PEDOT:PSS reduces acidity of the latter. This increased value of $\mathrm{pH}$ of PEDOT: PSS $-\mathrm{GeO}_{2}$ composite. When compared the PV 
performance of pristine PEDOT: PSS with PEDOT: PSS $-\mathrm{GeO}_{2}$ the latter exhibited higher stability. Addition of lithium bis(trifluoromethane)sulfonamide ( $\mathrm{Li}-\mathrm{TFSI}$ ) to spiro- OMeTAD always enhance the charge mobility and electrical conductivity. Oxidation reaction betweenspiro- OMeTAD and oxygen was facilitated by Li- TFSI. Various substitutes for spiro- OMeTAD are P3HT [94], PDPPDBTE, TTF (tetrathiafulvalene derivative) and $\mathrm{CuI}$.

\subsubsection{Electron Transport Materials (ETMs)}

In conventional and inverted architectural devices, $\mathrm{TiO}_{2}$ and $\mathrm{PCBM}$, which have intrinsic defects, are electron transport materials commonly used which abruptly facilitate perovskite device degradation. Pathak et al. [95] carried out research on the effect of $\mathrm{TiO}_{2}$ Photoanode doped aluminium on the performance and stability of device upon UV exposure and it showed improved efficiency and stability. Fakharuddin et al. [96] worked on performance and long-term stability of planar device with compact $\mathrm{TiO}_{2}$ layer and mesoporous devices with bare and $\mathrm{TiCl}_{4}$ - treated $\mathrm{TiO}_{2}$ nanorods scaffolds which showed that mesoporous device was more stable than planar device. PCBM as ETM in inverted devices is sensitive to ambient condition. The $\mathrm{n}$ - type $\mathrm{ZnO}$ nanoparticles was used to replace PCBM in the inverted device structure [97].

\subsubsection{Architectural Design of PSCs}

The planar architecture in PSCs has the advantage over mesoporous structure of being a simpler arrangement that is easier to fabricate [59,70, 97-100]. Each layer in planar architecture should be free of pin - hole and reduces the series resistance $R_{\text {sh }}$ as good contact is made with the adjacent layers and increase the shunt resistance $\mathrm{R}_{\text {sh }}$ [59]. The perovskite solar cells are unique in structure; self-doping and charge collection cannot be described by traditional approaches [101] - [103].

\section{Conclusions}

Review of the promising clean and efficient solar cells is stated. The PSCs originated from the world of dye sensitized solar cell. Different methods of fabrication were highlighted and likewise the advantage, disadvantages and PCEs achieved by using the methods.It was pinpointed that the factors that facilitates degradation of PSCs are Moisture, Oxygen, UV light irradiation, Temperature etc. Different steps have been taken by research to solve the issue of instability in PSCs like adopting mixed halides, replacement of cations, film morphology, interfacial modifications and devising new materials for HTMs, ETMs and architectural designs. For commercialization of PSCs to come through, the issue of short lifetime performance of this device has to be tackled.

\section{How to Cite this Article:}

C. Ezike, G. Kana, and A. Aina, "Progress and Prospect on Stability of Perovskite Photovoltaics", J. Mod. Mater., vol. 4, no. 1, pp. 16-30, May 2017. doi: 10.21467/jmm.4.1.16-30

\section{References}

[1] Liang, T.S., Zainal, Z., Tee, T.W., Hamadneh, I. Potentiostatic deposition of copper indium disulfide thin films: effect of cathodic potentials on the optical and photoelectrochemical properties, The Malaysia Journal of Analytical Science, 12(3), 600 - 608, 2008.

[2] Weiss, M.,Horn, J.,Ritcher, C.,Schlettwein, D. Preparation and characterization of methylammonium tin iodide layers as photovoltaic absorbers, Phys. Status Solidi A, 213(4), 975 - 981, 2015.

[3] Birkmire, R., Eser, E. Polycrystalline thin film solar cells: present status and future potential, Ann. Rev. Mater. Sci. 27, 625 - 653, 1997.

[4] Ameri, T., Dennier, G., Lungenschmeied, C., Brabec, C. J. Organic tandem solar cells: A review, Energ. Environ. Sci. 2, $347-363,2009$.

[5] Kumar, A., Hong, Z.R., Sista, S., Yang, Y. The critical role of processing and morphology in determining degradation rates in polymer solar cells, Adv. Energy Mater. Vol 1, no 1,pp $124-131.2011$.

[6] Hook, M., Tank, X. Depletion of fossil fuels and anthropogenic climate change -A review, Energy Policy, 52, 797-809, 2013.

[7] Henderson, D. O., Mu, R., Ueda, A., Wu, M. H., et al Optical and structural characterization of copper indium disulfide thin films. Materials and Design 22:585- 589.

[8] Noel, N.K., Stranks, S.D., Abate, A., Wehrenfennig, C., Guarnera, S., Haghighirad, A. A., Sadhanala, A., Eperon, G. E., Pathak, S. K., Johnston, M. B., Petrozza, A., Herz, L. M., Snaith, H. J. Lead - free organic - inorganic tin halide perovskite for photovoltaic applications, Energy and Environ. Sci. 7(9), 3061 - 3068, 2014.

[9] Malinkiewicz, O., Yella, A., Lee, Y.H., Espallarga, M., Graetzel, M., Nazeeruddin, M.K., Bolink, H. J. Perovskite solar cells employing organic chargetransport layers, Nature Photonics, 8, 128 - 132, 2013. 
[10] Lewis, N. S., Nocera, D. G. Powering the planet: Chemical challenges in solar energy utilization. Proc. Natl. Acad. Sci. USA, 103 (43) 15729-15735, 2006.

[11] Chung, I., Lee, B., He, J., Chang, R.P.H., Kanatzidis, M.G. All-solid-state dye-sensitized solar cells with high efficiency, .Nature, 485, 486 - 489. 2012.

[12] Huynh, W.U., Dittmer, J.J., Alivisatos, A. P. Hybrid nanorod - polymer solar cells, Science, 295, 2425 2427, 2002.

[13] Im, J. - H., Lee, C. - R., Lee, J. - W., Park, S. - W., Park, N. - G. $6.5 \%$ efficient perovskite quantum - dot sensitized solar cell, Nanoscale, 3 (10), 4088 - 4093, 2011.

[14] Muhammad, M. A., Sahamir, S.R., Datta, R. S., Long, B. D., Sabri, M.F., and Said, S.M. "A Review on the Fabrication of Polymer-Based Thermoelectric Materials and Fabrication Methods" The Scientific World Journal, vol 2013, 713640, pp 17, 2013.

[15] Xiong, J.,Yang, B.C., Zhou, C.H., Yang, J.L., Duan, H.C., Huang, W.I., Zhang, X., Xia, X.D., Zhang, L., Huang, H., Gao, Y.L. Enhanced efficiency and stability of polymer solar cells with $\mathrm{TiO}_{2}$ nanop s buffer layer, Org. Electron 15, 835 - 843, 2014.

[16] Yip, H.L., Jen, A.K.Y. Recent advances in solution processed interfacial materials for efficient and stable polymer solar cells, Energ. Environ. Sci. 5, 5994-6011, 2012

[17] Shang, H.X., Fan, H.J., Liu, Y., Hu, W.P., Li, Y.F., Zhan, X.W. A solution - processable star - shaped molecule for high - performance organic solar cells, Adv. Mater. 23, 1554 - 1557, 2011.

[18] Wu, J.B., Becerril, H.A., Bao, Z.N., Liu, Z.F., Chen, Y.S.,Peumans, P. Organic solar cells with solution processed grapheme transparent electrodes, Appl. Phys. Lett. 92, 2008.

[19] Zhou, H. P., Chen, Q., Li, G., Luo, S., Song, T. B., Duan, H. S., Hong, Z.R., You, J. B., liu, Y. S., Yang, Y. Photovoltaics: interface engineering of highly efficient perovskite solar cells, Science, 345, 542 - 546, 2014.

[20] Nie, W.Y., Tsai, H.H., Asadpour, R., Blancon, J.C., Neukirch, A.J., Gupta, G., Crochet, J.J., Chhowalla, M., Tretiak, S., Alam, M.A., Wang, H.L., Mohite, A.D. High efficiency solution - processed perovskite solar cells with millimeter - scale grains, Science 347, 522 - 525, 2015.

[21] Yang, W.S., Noh, J.H., Jeon, N.J., Kim, Y.C., Ryu, S., Seo, J., Seok, S.I. High - performance photovoltaic perovskite layers fabricated through intramolecular exchange, Science 348, 1234 - 1237, 2015.

[22] Yang, S., Fu, W., Zhang, Z., Chen, H., Li, C-Z. Recent Advances in Perovskite Solar Cells: Efficiency, Stability and Lead-free Perovskite, J. Mat. Chem. A 2017.

[23] O'Regan, B., Grätzel, M. A low-cost, high efficiency solar cell based on dye sensitized colloidal $\mathrm{TiO}_{2}$ films, Nature, 353(6346): 737 - 740, 1991.

[24] Hagfeldt, A., Boschloo, G., Sun, L., Kloo, L., Petterson, H. Dye-sensitized solar cells. Chemical Reviews, 7(6), $6595-6663,2010$.

[25] Mathew, S., Yella, S.A., Gao, P., Humphrey-Baker, R., Curchod, B.F.E., Ashari - Astani, N., tavernelli, I., Rothlisberger, U., Nazeerudin, M. K., and Grätzel, M. Dye-sensitized solar cells with $13 \%$ efficient achieved through the molecular engineering of porphyrin sensitizers, Nature Chemistry, 6 (3): 242 - 247, Nat Chem. 6(3): 242-247, 2014.
[26] Asghar, M.I., Miettunen, K., Halme, J., Vahermaa, P., Toivola, M., Aitola, K., and Lund, P. Review of stability for advanced dye solar cells, Energy and Environmental Science, 3(4), 418 - 426, 2010.

[27] Halme, J., Vaherma, P., Miettunen, K., Lund, P.. Device Physics of Dye Solar Cells, Adv. Mater. 22 (35), E210 E234, 2010.

[28] Bach, U., Lupo, D., Comte, P., Moser, J.E., Weissortel, F., Salbeck, J., Spreitzer, and Grätzel, M. Solid - state dye - sensitized mesoporous $\mathrm{TiO}_{2}$ solar cells with high photon-to -electron conversion efficiencies, Nature, 395 (6702), 583 - 585, 1998.

[29] Boix, P. P., Nonomura, K., Mathews, N., Mhaisalkar, S. G. Current progress and future perspectives for organic/inorganic perovskite solar cells, Mater. Today, 17(1), 16 -23. 2014.

[30] Petrović, M.,Chellappan, V., Ramakrishna, S. Perovskites: solar cells \& engineering applications materials and device development, Solar Energy, 122, $678-699,2015$.

[31] Stranks, S.D., Nayak, P.K., Zhang, W., Stergiopoulos, T., Snaith, H.J. Formation of thin films of organic inorganic perovskite for high - efficiency solar cells, Angew. Chem. Int. Ed., 54 (11), 3240 - 3248, 2015.

[32] Snaith, H. J. Perovskites: the emergence of a new era for low- cost high efficiency solar cells, J. Phys. Chem. Lett., 4 (21), 3623 - 3630, 2013.

[33] Hao, F., Stoumpos, C. C.,Cao, D. H., Chang, R. P. H., Kanatzidis, M. G. "Lead - free solid - state organic inorganic halide perovskite solar cells" Nat. Photon, 8, 489-494, 2014.

[34] Stamplecoskie, K.G., Manser, J.S., Kamat, P.V. Dual nature of the excited stated in organic - inorganic lead halide perovskite, Energy Environ. Sci. 2014.

[35] Stranks, S.D., Nayak, P.K., Zhang, W., Stergiopoulos, T., Snaith, H.J. Formation of thin films of organic inorganic perovskite for high - efficiency solar cells, Angew. Chem. Int. Ed., vol 54, no 11, pp. 3240-3248, 2015.

[36] Kojima, A. Teshima, K., Shirai, Y., Miyasaka, T. Organometal halide perovskites as visible - light sensitizers for photovoltaic cells, J. Am. Chem. Soc., 131(17) 6050 - 6051. 2009.

[37] Lee, M. M., Teuscher, J., Miyaska, T., Murakami, T.N., Snaith, H.J. Efficient hybrid solar cells based on mesosuperstructured organometal halide perovskites, Science, vol. 338, (6107), 643 - 647, 2012.

[38] Körbel, S. M., Marques, M. and Botti, S. Stability and electronic properties of new inorganic perovskites from high-throughput ab initio calculations, J. Mater. Chem. C, vol 4, pp. 3157-3167, 2016.

[39] Mitzi, D. B., Wang, S., Field, C. A., Chess, C. A, Gluoy, M. A. Conducting layered organic - inorganic halides containing $\langle 110\rangle$ - oriented perovskite sheets, Scence, 267(5203), 1473 - 1476, 1995.

[40] Li, C., Lu, X., Ding, W., Feng, L., Goa, Y., Guo, Z. Formability of $\mathrm{ABX}_{3}(\mathrm{X}=\mathrm{F}, \mathrm{Cl}, \mathrm{Br}, \mathrm{I})$ halide perovskites. Acta Crystallographica B, 64, 702 - 707, 2008.

[41] Cohen, B. N., Labarca, C., Davidson, N., Lester, H. A. Mutations in M2 alter the selectivity of the mouse nicotinic acetylcholine receptor for organic and alkali metal cations, Journal of general Physiology, 100(3), pp. 373 - 400, 1992.

[42] Mckinnon, N. K., Reeves, D.C., Akabas, M.H. 5 - HT3 receptor ion size selectivity is a property of the transmenbrane channel, not the cytoplasmic vestibule 
portals, Journal of General physiology, 138 (4), 453466, 2011.

[43] Im, J - H., Chung, J., Kim, S.-J., Park, N. - G. Synthesis structure, and photovoltaic property of a nanocrystalline $2 \mathrm{H}$ perovskite- type novel sensitizer $\left(\mathrm{CH}_{3} \mathrm{CH}_{2} \mathrm{NH}_{3}\right) \mathrm{PbI}_{3}$, Nanoscale Research Letters, 7, 353, 2012.

[44] Sanchez, R.S., Gonzalez - Pedro, V., Lee, J.-W. et al Slow dynamic processes in lead halide perovskite solar cells: characteristic times and hysteresis, Journal of Physical Chemistry Letters, 5 (13), 2357 - 2363, 2014.

[45] Eperon, G.E., Stranks, S.D., Melelaou, C., Johnson, M., Herz, L.M., Snaith, H.J. Formamidinium lead trihalide: a broadly tunable perovskite for efficient planar heterojunction solar cells, Energy Environ. Sci. 7, $982-$ 988, 2014.

[46] Lv, S.; Pang,S.; Zhou, Y.; Padture, N. P.; Hu,H.; Wang , L.; Zhou, X.; Zhu, H.; Zhang, L.; Huang, C.; Cui , G.One - step, solution - processed formamidinium lead trihalide (FAPbI3-xClx) for mescopic perovskite polymer solar cells, Physical Chemistry Chemical Physics, 16(36), 19206 - 19211, 2014.

[47] Pang, S., Hu, H., Zhang, J. et al. $\mathrm{NH}_{2} \mathrm{CH}=\mathrm{NH}_{2} \mathrm{PbI}_{3}$ : an alternative organolead iodide perovskite sensitizer for mesoscopic solar cells, Chemistry of Materials, 26 (3), 1485 - 1491, 2014.

[48] Kim, H.-S.; Lee, C.-R.; Im, J.-H.; Lee, K.-B.; Moehl, T.; Marchioro, A.; Moon, S.-J.; Humphry-Baker, R.; Yum, J.-H.; Moser, J. E. Lead Iodide Perovskite Sensitized All-Solid-State Submicron Thin Film Mesoscopic Solar Cell with Efficiency Exceeding 9\%, Sci. Rep., 2, 591, 2012.

[49] Wehrenfennig, C.; Liu, M.; Snaith, H. J.; Johnston, M. B.; Herz, I. Charge-Carrier Dynamics in VapourDeposited Films of the Organolead Halide Perovskite $\mathrm{CH}_{3} \mathrm{NH}_{3} \mathrm{PbI}_{3-\mathrm{x}} \mathrm{Cl}_{\mathrm{x}}$, Energy and Environ. Sci., 7, 2269 2275, 2014.

[50] Heo, J.H.; Song, D.H.; Patil, B.R.; Im, S.H. Recent Progress of Innovative Perovskite Hybrid Solar Cells.Isr. J. Chem., 55 (9), 966-977, 2015.

[51] Liu, M., Johnston, M.B., Snaith, H.J. Efficient Planar heterojunction perovskite Solar Cells by vapour deposition, Nature, 501, 395-398,2013.

[52] Ball, J. M., Lee, M. M., Hey, A., Snaith, H. J. Lowtemperature processed meso- superstructured to thinfilm solar cells, Energy Environ. Sci., 6, 1739-1743, 2013.

[53] Burlakov, V. M., Eperon, G. E., Snaith, H. J., Chapman, S. J., Goriely, A. Controlling coverage of solution cast materials with unfavourable surface interactions Appl. Phys. Lett., 104, 091602, 2014.

[54] Stranks, S. D., Eperon, G.E., Grancini, G., Menelaou, C., Alcocer, M.J.P., Leijtens, T., Herz, L. M., Petrozza, A., Snaith, H. J. Electron - hole diffusion lengths exceeding 1 micrometer in an organometal trihalide perovskite absorber, Science, 342(6156), 341 -344, 2013.

[55] Yang, W.S.; Noh, J.H.; Jeon, N.J.; Kim, Y.C.; Ryu, S.; Seo, J.; Seok, S.I. High-performance photovoltaic perovskite layers fabricated through intramolecular exchange. Science, 6240,1234-1237, 2015.

[56] Liang, K., Mitzi, D. B., Prikas, M. T. Synthesis and Characterization of Organic-Inorganic Perovskite Thin Films Prepared Using a Versatile Two-Step Dipping Technique, Chem. Mater., 10(1), 403 - 411, 1998.

[57] Elumalai, N. K., Mahmud, Md A., Wang, D. and Uddin, A. Perovskite Solar Cells: Progress and Advancements, Energies, 9, 861, 2016.
[58] Burschka, J.,Pellet, N., Moon S.J., Humphrey-Baker, R., Wang, P., Zakeeruddin, S.M., and Grätzel, M. Sequential deposition as a route to high- performance perovskite sensitized solar cells. Nature, 499 (7458): 316 - 319, 2013.

[59] Huang, F., Dkhissi, Y., Huang, W., Xiao, M., Benesperi, et al, "Gas - assisted preparation of lead iodide perovskite films consisting of a monolayer of single crystalline grains for high efficiency planar solar cells" Nano energy, vol 10. pp 10-18, 2014.

[60] Li, W.; Fan, J.; Li, J.; Mai, Y.; Wang, L. Controllable Grain Morphology of Perovskite Absorber Film by Molecular Self-Assembly toward Efficient Solar Cell Exceeding 17\%. J. Am. Chem. Soc., 137 (32), 1039910405, 2015.

[61] Bai, S.; Wu, Z.; Wu, X.; Jin, Y.; Zhao, N.; Chen, Z.; Mei, Q.; Wang, X.; Ye, Z.; Song, T.; Liu, R.; et al. Highperformance planar heterojunction perovskite solar cells: Preserving long charge carrier diffusion lengths and interfacial engineering. Nano Res. 7, 1749-1758, 2014.

[62] Abbas, H., Kottokkaran, R., Balaji, G., Samie, M., Zhang, L. and Dalal, V. L. High efficient sequentially vapor grown n-i-p CH3NH3PbI3 perovskite solar cells with undoped $\mathrm{P} 3 \mathrm{HT}$ as p-type heterojunction layer, APL Mat. 3, 016105, 2015.

[63] Yao, K., Wang, X., Xu, Y-X., Li, F. A general fabrication procedure for efficient and stable planar perovskite solar cells: morphological and interfacial control by in-situgeneral layered perovskite, Nano energy, vol 18, pp. 165175, 2015.

[64] Brittman, S., Adhyaksa, G. W.P. and Garnett, E.C. The expanding world of hybrid perovskites: materials properties and emerging applications, MRS Communication, 5 (1), 7-26, 2015.

[65] Frost, J. M., Butler, K.T., Brivio, F., Hendon, C.H., Schilfgaarde, M.V.,Walsh, A. Atomistic origins of high - performance in hybrid halide perovskite solar cells, Nano Lett. 14 (5), pp 2584-2590, 2014.

[66] Kim, H. - S., Lee, J. - W., Yantara, N., Boix, P. P., Kulkarni, S. A., Mhaisakar, S., Gratzel, M., Park, N. - G. High efficiency solid - state sensitized solar cell - based on submicrometer rutile $\mathrm{TiO}_{2}$ nanorod and $\mathrm{CH}_{3} \mathrm{NH}_{3} \mathrm{PbI}_{3}$ perovskite sensitizers, Nano Lett., 13 (6), pp 2412-2417, 2013.

[67] Ko, H. - S., Lee, J. - W., Park, N. - G. 15.76\% efficiency perovskite solar cell prepared under high relative humidity: Importance of $\mathrm{PbI}_{2}$ morphology in two step deposition of $\mathrm{CH}_{3} \mathrm{NH}_{3} \mathrm{PbI}_{3}$, J. Mater. Chem. A., vol 3, pp. 8808-8815, 2015.

[68] Li, B., Li, Y., Zheng, C., Gao, D., Huang, W. Advancements in the stability of perovskite solar cells: degradation mechanisms and improvement approaches. RSC adv., 6, 38079 - 38091, 2016.

[69] Berhe, T. A., Su, W-N., Chen, C-H., Pan, C-J., Cheng, JH., Chen, H-M., Tsai, M-C., Chen, L-Y., Amare Aregahegn Dubale, A. A and Hwang, B-J, Organometal halide perovskite solar cells: degradation and stability, Energy Environ. Sci., 9, 323-356, 2016.

[70] You, J. B., Hong, Z. R., Song, T. - B., Meng, L., Liu et al. "Moisture assisted perovskite film growth for high performance solar cells". Appl. Phys. Lett., 105, 183902, 2014.

[71] Bass, K. K., Mcanally, R. E., Zhou, S., Djurovich, P.I., Thompson, M. E., Melot, B.C. Influence of moisture on the preparation, crystal structure, and photophysical 
properties of organohalide perovskites, Chem. Commun., 50, 15819 - 15822, 2014.

[72] Wu, C. - G., Chiang, C. - H., Tseng, Z. - L., Nazeeruddin, M. K., Hagfeldt, A., Gratzel, M. High efficiency stable inverted perovskite solar cells without current hysteresis, Energy and Environ. Sci., 8, 2725 2733, 2015.

[73] Niu, G. D., Guo, X. D., Wang, L.D. Review of recent progress in chemical stability of perovskite solar cells, $J$. Mater. Chem. A., 3, 8970 - 8980, 2015

[74] Niu, G. D., Li, W. Z., Meng, F. Q., Wang, L. D., Dong, H. P., Qiu, Y. Study on the stability of $\mathrm{CH}_{3} \mathrm{NH}_{3} \mathrm{PbI}_{3}$ films and the effect of post modification by aluminium oxide in all solid - state hybrid solar cells, J. Mater. Chem. A, 2, $705-710,2014$.

[75] Yang, W.S., Noh, J.H., Jeon, N.J., Kim, Y.C., Ryu, S., Seo, J., Seok, S.I. High - performance photovoltaic perovskite layers fabricated through intramolecular exchange, Science 348(6240), 1234 - 1237, 2015.

[76] Christians, J. A., Miranda Herera, P. A., Kamat, P. V. Transformation of the excited state and photovoltaic efficiency of $\mathrm{CH}_{3} \mathrm{NH}_{3} \mathrm{PbI}_{3}$ perovskite upon controlled exposure to humidified air, J. Am. Chem. Soc., 137, 1530 $-1538,2015$.

[77] Mosconi, E., Azpiroz, J. M., Angelis, F. De. Ab initio molecular dynamic simulation of methylammonium lead iodide perovskite degradation by water, Chem. Mater., 27 (13), 4885 - 4892, 2015.

[78] Huan, Y., Meyer, S., Dkhissi, Y., Weber, K., Pringle, J.M., Bach, U., Spiccia, L., Cheng, Y. Degradation observations of encapsulated planar $\mathrm{CH}_{3} \mathrm{NH}_{3} \mathrm{PbI}_{3}$ perovskite solar cells at high temperatures and humidity, J.Mater. Chem. A, 3, 8139-8147, 2015.

[79] Aristidou, N., Sanchez - Molina, I., Chotchuangchutchaval, T., Brown, M., Martinez, L., Rath, T., Haque, S. A. The Role of Oxygen in the Degradation of Methylammonium Lead Trihalide Perovskite Photoactive Layers. Angew. Chem. Int. Ed., 54, 8208-8212, 2015

[80] Leijtens, T., Eperon, G. E., Pathak, S., Abate, A., Lee, M. M., Snaith, H. J. Overcoming ultraviolet light instability of sensitized $\mathrm{TiO}_{2}$ with meso - superstructured organometal tri - halide perovskite solar cells, Nat. Commun., 4, 2885, 2013.

[81] Ito, S., Tanaka, S., Manabe, K., Nishino, H. Effects of surface blocking layer of $\mathrm{Sb}_{2} \mathrm{~S}_{3}$ on nanocrystalline $\mathrm{TiO}_{2}$ for $\mathrm{CH}_{3} \mathrm{NH}_{3} \mathrm{PbI}_{3}$ perovskite solar cells, J. Phys. Chem. C, 118(30), 16995 - 17000,2014.

[82] Conings, B., Dijkoningen, J., Gauquelin, N., Babayigit, A., D’Haen, J., D’Olieslaeger, L., Ethirajan, A., Verbeeck, J., Manca, J., Mosconi, E., Angelis, F.D., Boyen, H. - G. Intrinsic Thermal Instability of Methylammonium Lead Trihalide Perovskite, $A d v$. Energy Mater., 5(15), 1500477, 2015.

[83] Philippe, B.; Park, B.-W.; Lindblad, R.; Oscarsson, J.; Ahmadi, S.; Johansson, E.M.J.; Rensmo, H. Chemical and Electronic Structure Characterization of Lead Halide Perovskites and Stability Behavior under Different Exposures-A Photoelectron Spectroscopy Investigation. Chem. Mater. 27(5), 1720-1731, 2015.

[84] Misra, R. K.,Aharon, S., Li, B., Mogilyansky, D., Visolyfisher, I., Etgar, L., Katz, E. A. "Temperature - and component - dependent degradation of perovskite photovoltaic materials under concentrated sunlight" $J$. Phys. Chem. Lett., 6 (3), 326 - 330, 2015.
[85] Leong, W. L., Ooi, Z.E., Sabba, D., Yi, C., Zakeeruddin, S.M., Graetzel, M., Gordon, J. M, Katz, E. A., Mathews, N. Identifying Fundamental Limitations in Halide Perovskite Solar Cells., Adv. Mater., 28 (12), 24392445, 2016.

[86] Zhang, M., Lyu, M. Q., Yu, H., Yun, J. H., Wang, Q., Wang, L. Z. Stable and low-cost mesoscopic $\mathrm{CH}_{3} \mathrm{NH}_{3} \mathrm{PbI}_{2} \mathrm{Br}$ perovskite solar cells by using a thin poly(3-hexylthiophene) layer as a holew transporter, Chem. - Eur. J., 21(1), 434 - 439, 2015.

[87] Jiang, Q. 1., Rebollar, D.,Gong, J., Piacentino, E. L., Zheng, C., Xu, T. Pseudohalide-induced moisture tolerance in perovskite $\mathrm{CH} 3 \mathrm{NH} 3 \mathrm{~Pb}(\mathrm{SCN}) 2$ I thin films, Angew. Chem. Int. Ed., 54(26), 7617 - 7620, 2015.

[88] Eperon, G. E., Burlakov, V. M., Docampo, P., Goriely, A., Snaith, H. J. Morpholgical control for high performance, solution - processed planar heterojunction perovskite solar cells, Adv. Funct. Mater., 24(1), 151 157, 2014.

[89] Lyu, M., Yun, J-H., Cai, M., Jiao, Y., Bernhardt, P. V., Zhang, M., Wang, Q., Du, A., Wang, H., Liu, G., and Wang, L. Organic-inorganic bismuth (III)-based material: A leadfree, air-stable and solution-processable light-absorber beyond organolead perovskites, Nano Research, 9, 692, 2016.

[90] Chen, Q., Marco, N. De, Yang, Y., Song, T. - B., Chen, C. - C., Zhao, H. X., Hong, Z. R., Zhou, H. P., Yang, Y. Under the spotlight: The organic-inorganic hybrid halide perovskite for optoelectronic applications, Nano Today, 10 (3), 355 - 396, 2015.

[91] Kim, B.J., Kim, D. H, Lee, Y. et al. "Highly efficient and blending durable perovskite solar cells: towards a wearable power source" Energy \& Environmental Science, 8(3), 916-921, 2015.

[92] Qian, M., Li, M., Shi, X. B., Ma, H.,Wang, Z. K., Liao, L.S. Planar perovskite solar cells with $15.75 \%$ power conversion efficiency by cathode and anode modification, J. Mater. Chem. A, 3, 13533 - 13539, 2015.

[93] Zheng, H., Zhu, X., Liang, Y., Guo, X. Interfacial layer engineering for performance enhancement in polymer solar cells, Polymers, 7(2), 333 - 372, 2015.

[94] Xiao, Z., Bi, C., Shao, Y. Y. C., Dong, Q. F., Wang, Q., Yuan, Y. B., Wang, C. G., Gao, Y. L. Huang, J. S. Efficient, high yield perovskite photovoltaic devices grown by interdiffusion of solution - processed precursor stacking layers, Energy \& Environ. Science,7(8), 2619-2623, 2014.

[95] Pathak, S. K., Abate, A., Leijtens, T. et al. Towards long - term photostability of solid - state dye sensitized solar cells, Adv. Energy Materials, 4(8),1301667,2014.

[96] Fakharuddin, A.; Di Giacomo, F.; Ahmed, I.; Wali, Q.; Brown, T.M.; Jose, R. Role of morphology and crystallinity of nanorod and planar electron transport layers on the performance and long term durability of perovskite solar cells. J. Power Sources, 283, 61-67, 2015 .

[97] Jeng, J. - Y., Chiang, Y.-F., Lee, M.-H., Peng, S.-R., Guo, T.-F., Cheng, P., Wen, T.-C. CH3NH3PbI3 perovskite/fullerene planar-heterojunction hybrid solar cells. ,Adv. Mater., 25 (27), 3727 - 3732, 2013.

[98] Docampo, P., Ball, J. M., Darwich, M., Eperon, G.E., Snaith, H.J. Efficient organometal trihalide perovskite planar-heterojunction solar cells on flexible polymer substrates, Nat. Commun., 4:2761, 1-6, 2013. 
[99] Roldan - Carmona, C., Malinkiewicz, O., Soriano, A., Espallargas, G. M., Garcia, A., Reinecke, P., Kroyer, T., Dar, M.I., Nazeeruddin, M. K., Bolink, H. J. Flexible high efficiency perovskite solar cells, Energy Environ. Sci., 7, $994-997,2014$.

[100] Sun, S., Salim, T., Mathews, N., Duchamp, M., Boothroyd, C., Xing, G., Sum, T. C, Lam, Y. M. The origin of high efficiency in low - temperature solution processable bilayer organometal halide hybrid solar cells, Energy Environ. Sci., 7, 399 - 407, 2014.

[101] Hejri, M., Mokhtari, H., Azizian, M. R.,Ghandhari, M., Soder, L. On the parameter extraction of a five parameter double - diode model of photovoltaic cells and modules, IEEE J. Photovoltaics, 4(3), 915 - 923, 2014.

[102] Ishaque, K.,Salam, Z., Taheri, H. "Simple, fast and accurate two - diode model for photovoltaics modules"Sol. Energy Mater. Sol. Cells, 95(2), 586 - 594, 2011.

[103] Sun, X., Asadpour, R., Nie, W., Mohite, A.D., Alam, M.A. A Physics - based analytical model for perovskite solar cells, IEEE J. of Photovoltaics, 5 (5), 1389-1394, 2015.
Publish your research article in AIJR journals$\checkmark \quad$ Online Submission and Tracking

$\checkmark$ Peer-Reviewed

$\checkmark$ Rapid decision

$\checkmark \quad$ Immediate Publication after acceptance

$\checkmark \quad$ Articles freely available online

$\checkmark \quad$ Retain full copyright of your article.

Submit your article at journals.aijr.in

\section{Publish your books with AIJR publisher-}

$\checkmark$ Publish with ISBN and DOI.

$\checkmark$ Publish Thesis/Dissertation as Monograph.

$\checkmark$ Publish Book Monograph.

$\checkmark$ Publish Edited Volume/ Book.

$\checkmark$ Publish Conference Proceedings

$\checkmark \quad$ Retain full copyright of your books.

Submit your manuscript at books.aijr.org 